\title{
The Impact of Stand Age and Fertilization on the Soil Microbiome of Miscanthus $\times$ giganteus
}

\author{
Lanying Ma, ${ }^{1,2}$ Fernando Igne Rocha, ${ }^{1,3}$ Jaejin Lee, ${ }^{1,2}$ Jinlyung Choi, ${ }^{1,2}$ Mauricio Tejera ${ }^{4}$, Thanwalee Sooksa-Nguan, ${ }^{1,2}$ Nicholas \\ Boersma, ${ }^{2,4}$ Andy VanLoocke, ${ }^{2,4}$ Emily Heaton, ${ }^{2,4}$ and Adina Howe ${ }^{1,2, \dagger}$ \\ ${ }^{1}$ Department of Agricultural and Biosystems Engineering, lowa State University, Ames, IA, U.S.A. \\ ${ }^{2}$ Center for Advanced Bioenergy and Bioproducts Innovation, Urbana, IL, U.S.A. \\ ${ }^{3}$ Department of Soil, Universidade Federal Rural do Rio de Janeiro, Seropédica, Brazil \\ ${ }^{4}$ Department of Agronomy, lowa State University, Ames, IA, U.S.A.
}

Accepted for publication 1 November 2020.

\section{ABSTRACT}

Yield of the perennial grass Miscanthus $\times$ giganteus has shown an inconsistent and unpredictable response to nitrogen $(\mathrm{N})$ fertilizer, yet fertilization underpins the crop's environmental and economic sustainability. The interactions among soil microbial communities, $\mathrm{N}$ availability, and Miscanthus $\times$ giganteus and management may explain changes in plant productivity. In this study, soil samples from different stand ages of Miscanthus $\times$ giganteus in a replicated chronosequence field trial were used to investigate the effects of stand age and $\mathrm{N}$ fertilizer rates on microbial community structure. We hypothesized that there is a definable Miscanthus $\times$ giganteus soil microbiome and that this community varies significantly with stand age and fertilization. Our results showed that the main phyla in soil microbial communities, regardless of plant age, are similar but microbial community structures are significantly different. The variation in observed microbial communities generally decreases with older stand ages. The amount of $\mathrm{N}$ fertilizer applied also affected the microbial community structure associated with different aged Miscanthus $\times$ giganteus. Specifically, the relative abundance of Proteobacteria (Alphaproteobacteria and Gammaproteobacteria) and Acidobacteria (subgroup Gp1) increased shortly after fertilization and was more associated with younger Miscanthus $\times$ giganteus. Furthermore, our results show a significant relationship between bacterial $\alpha$ diversity and fertilization rates and that this response is also affected by stand age. Overall, our results emphasize linkages between microbial community structure, plant age, and fertilization in Miscanthus $\times$ giganteus.

Keywords: agronomy, management, microbiome, Miscanthus $\times$ giganteus, nitrogen response, soil bacterial community structure, soils, staggered start experiment
${ }^{\dagger}$ Corresponding author: A. Howe; adina@iastate.edu

Funding: This work was funded by the Department of Energy (DOE) Center for Advanced Bioenergy and Bioproducts Innovation (U.S. DOE, Office of Science, Office of Biological and Environmental Research under award number DESC0018420). The Long-term Assessment of Miscanthus Productivity and Sustainability experiment was funded by United States Department of Agriculture (USDA) National Institute of Food and Agriculture Hatch grant 1008969, the Leopold Center for Sustainable Agriculture, and the Iowa State University Department of Agronomy. F. I. Rocha was also supported by Coordenação de Aperfeiçoamento de Pessoal de Nivel Superior, Brazil (CAPES; PDSE call number 41/2018). Partial support was also provided by USDA Hatch Project IOW04414.

*The $e$-Xtra logo stands for "electronic extra" and indicates that supplementary figures and supplementary tables are published online.

The author(s) declare no conflict of interest.
Perennial biomass crops promise to provide both renewable energy and ecosystem services; however, their sustainability hinges critically on crop management (Davis et al. 2013). Harnessing the phytobiome may increase the sustainability of these crops by increasing nutrient use efficiency and, thus, reducing the need for economically and environmentally expensive synthetic nitrogen $(\mathrm{N})$ fertilizer (Robertson et al. 2017). In temperate rainfed regions, the grass Miscanthus $\times$ giganteus (Greef et Deu.) stands out as a potential bioenergy crop because of its high yields and low-input requirements (Heaton et al. 2004, 2008, 2010). Furthermore, it has relatively high cold tolerance while still producing high yields of lignocellulosic biomass (LeBauer et al. 2017; Wang et al. 2008). Estimates of the maximum rainfed simulated end-of-growth-season biomass are approximately $40 \mathrm{Mg}$ $\mathrm{ha}^{-1}$ for Miscanthus $\times$ giganteus, twice as much as switchgrass estimates (LeBauer et al. 2017; Miguez et al. 2012).

Despite high potential as a bioenergy feedstock, the most appropriate management strategies for the growth of Miscanthus $\times$ 
giganteus are still being explored, especially with regard to fertilization needs (Tejera et al. 2019). Generally, the long-term growth of Miscanthus $\times$ giganteus would result in the eventual depletion of soil $\mathrm{N}$ and, thus, fertilization is recommended (Cadoux et al. 2012). However, previous studies have reported inconsistent responses of Miscanthus $\times$ giganteus to $\mathrm{N}$ fertilization (LeBauer et al. 2017). For instance, Miscanthus $\times$ giganteus yields have been shown to increase as a result of increased $\mathrm{N}$ supply $(0,60$, and $120 \mathrm{~kg} \mathrm{ha}^{-1}$ ) in a Mediterranean climate (Cosentino et al. 2007). Similarly, N fertilization was found to have a positive effect on yield in Europe (Ercoli et al. 1999; Iqbal et al. 2015; Stępień et al. 2014). In contrast, no significant fertilizer effects on yield of Miscanthus $\times$ giganteus were observed at rates 0,60 , and $120 \mathrm{~kg}$ $\mathrm{ha}^{-1}$ in England (Christian et al. 2008) or with ammonium nitrate at rates of 0 and $100 \mathrm{~kg} \mathrm{ha}^{-1}$ in North Carolina (Christian et al. 2008; Rinta-Kanto et al. 2005; Teat et al. 2015). These inconsistent observations of Miscanthus $\times$ giganteus response likely represent variations in environmental conditions and soil types as well as sources of N. Another potential reason for the observed differences may be the stand ages of the Miscanthus $\times$ giganteus in the various studies, where annual harvesting may cause $\mathrm{N}$ depletion in the soils (Arundale et al. 2014). For example, specific Miscanthus $\times$ giganteus plants were found to respond to $\mathrm{N}$ fertilizer only after the third growing season (Miguez et al. 2008).

One of the factors affecting the availability of $\mathrm{N}$ to plants is the soil's underlying microbial communities (Moreau et al. 2019; Tao et al. 2019). In Miscanthus $\times$ giganteus, this microbial community has been identified to provide benefits associated with biological $\mathrm{N}$ fixation (Christian et al. 1997; Davis et al. 2010; Keymer and Kent 2014). Our understanding of soil, plant, and microbial community interactions helps to guide sustainable agroecosystem management (e.g., $\mathrm{N}$ additions). Similar to observations of biomass yield, soil microbial communities of Miscanthus $\times$ giganteus have been observed to have inconsistent responses to $\mathrm{N}$ fertilization. In a long-term field experiment, $\mathrm{N}$ fertilization had little effect on soil microbial communities (Liu and Ludewig 2019). In a study of Miscanthus $\times$ giganteus from four sites in Illinois, Kentucky, Nebraska, and New Jersey, no significant differences in $\mathrm{N}$-fixing microbial communities were observed between $\mathrm{N}$ application rates (Li et al. 2016). In contrast, the microbial composition and biomass of 5-year-old stands of Miscanthus $\times$ giganteus were observed to change significantly as a result of fertilization (Oates et al. 2016). It is possible that these observed mixed responses of Miscanthus $\times$ giganteus to fertilization could be associated with its perennial lifestyle and studying plants at different stages of establishment. The high N-use efficiency and low $\mathrm{N}$ leaching of Miscanthus $\times$ giganteus has previously been attributed to the plant's ability to translocate nutrients to rhizomes at the end of the growing season (Beale and Long 1997). Potentially, as a stand ages and the associated rhizomes mature, the plant's capacity to store nutrients and associated microbial communities may change.

In this study, we explore the relationships of $\mathrm{N}$ fertilization on Miscanthus $\times$ giganteus of varying stand ages and its associated soil bacterial communities. Unlike previous studies that assessed stand age effects by following the same stands over multiple growing seasons, we used a staggered-start experimental design (Loughin 2006), in which we planted replicated plots of Miscanthus $\times$ giganteus over 3 years within a randomized plot layout (Supplementary Fig. S1). This allowed us to compare replicated stands of different ages of Miscanthus $\times$ giganteus within the 2018 growing season (Tejera et al. 2019) and to separate the effect of stand age from that of the seasonal environment. We compared three stand ages of Miscanthus $\times$ giganteus and three $\mathrm{N}$ fertilization rates $\left(0,224\right.$, and $\left.448 \mathrm{~kg} \mathrm{ha}^{-1}\right)$ during one growing season. We hypothesized that diversity and membership of microbial communities within the soils of Miscanthus $\times$ giganteus are influenced by stand age and $\mathrm{N}$ fertilization rate. Furthermore, we expect that there is a relationship between observed diversity and aboveground biomass production of Miscanthus $\times$ giganteus. Identification of the relationships between diversity, microbial composition, stand age, fertilization, and productivity will help to better predict their impacts on Miscanthus $\times$ giganteus sustainable growth.

\section{MATERIALS AND METHODS}

Site description. This study used the Long-term Assessment of Miscanthus Productivity and Sustainability site located in central Iowa $\left(42.013^{\circ} \mathrm{N}, 93.743^{\circ} \mathrm{W}\right)$. The site has poorly drained soil (fineloamy, mixed, superactive, mesic Typic Endoaquoll) and four replications of each growing treatment, as previously described (Tejera et al. 2019). In summary, treatment levels included three planting years $(2015,2016$, and 2017) in 24-by-120-m main plots with split-plot treatments of five $\mathrm{N}$ fertilization rates $(0,112,224$, 336 , and $448 \mathrm{~kg} \mathrm{ha}^{-1}$ ) in 24-by-12 m plots (Supplementary Fig. S1). Miscanthus $\times$ giganteus clone Freedom (AgGrow Tech, Greensboro, NC, U.S.A.) was planted in 0.3-m rows at a density of approximately 11 rhizomes $\mathrm{m}^{-2}$ by a specialized plot planter. This clone has no discernible genetic differences from the Illinois or Hornum clones used elsewhere in the literature (Głowacka et al. 2015). With the exception of plots with no fertilization, $\mathrm{N}$ fertilization was annually applied as an aqueous solution of urea-ammonium nitrate in a single application. Fertilizer was side dressed into the soil at $0.1 \mathrm{~m}$ in depth, following coulter wheels spaced $1.5 \mathrm{~m}$ apart that cut field residue and opened the soil to avoid surface plant residue. For the year of this study, N fertilizer was applied on 9 May 2018. Historically, herbicide was applied to all stand ages during their first 2 years of growth to control weeds, and standing biomass was annually removed midwinter after full crop senescence and substantial leaf drop (Tejera et al. 2019). Standing crop biomass was measured on 13 November 2018 in two 1-m quadrants per plot following the methods of Tejera et al. (2019) (Supplementary Table S1).

Sampling and DNA extraction. Soil samples were taken in 2018 from plots planted with Miscanthus $\times$ giganteus in 2015, 2016, and 2017 representing 4-year, 3-year, and 2-year stand ages, respectively. Fertilizer was applied on 9 May. Soils from blocks treated with $\mathrm{N}$ fertilizer at 0,224 , and $448 \mathrm{~kg} \mathrm{ha}^{-1}$ were collected on 25 April, 30 April, 14 May, 30 May, and 3 July 3 or $-14,-10$, 5, 21, and 55 days relative to fertilization, respectively. Bulk soils were obtained from within a $10-\mathrm{cm}$ radius of the plant using a sampling core with a $30.5-\mathrm{cm}$ wet-sample tube $1.75 \mathrm{~cm}$ in diameter (Clements Associates Inc., Newton, IA, U.S.A.). Roots collected within the sample were not separated. The first $10-\mathrm{cm}$ depth of soil was collected and stored immediately in sampling bags on dry ice; samples were stored at $-80^{\circ} \mathrm{C}$ upon return to the laboratory. For each plot, two to three samples were obtained and analyzed independently (e.g., not composited). In total, 432 samples were collected (four blocks by three plots by three fertilization rates by five sampling days by two to three replicates). For DNA extraction, each soil sample was homogenized and aliquoted into a 0.25 -g subsample. DNA extraction was performed using the MagAttract PowerSoil DNA EP kit for DNA (Qiagen, Germantown, MD, U.S.A.) following the standard protocol of this kit and the liquid handling of the Eppendorf epMotion 5075 (Eppendorf, Enfield, CT, U.S.A.).

$16 S$ ribosomal RNA gene amplicon sequencing. DNA samples with concentration above $10 \mathrm{ng} \mu \mathrm{l}^{-1}$ were diluted to $10 \mathrm{ng} \mu \mathrm{l}^{-1}$ prior to sequencing. Samples with concentration lower than $10 \mathrm{ng} \mu \mathrm{l}^{-1}$ were submitted directly for amplicon sequencing. In summary, the V4 region of the bacterial 16S ribosomal RNA (rRNA) gene was amplified. Amplification was performed using $10 \mu \mathrm{M}$ each of $16 \mathrm{~S}$ rRNA v4 region primers. The forward primer $(515 \mathrm{~F})$ used was 
GTGYCAGCMGCCGCGGTAA and the reverse primer (806R) used was GGACTACNVGGGTWTCTAAT. The target amplicon size was $390 \mathrm{bp}$. The PCR amplification parameters were as follows for a 384-well plate: $94^{\circ} \mathrm{C}$ for $3 \mathrm{~min}$; then, $94^{\circ} \mathrm{C}$ for $60 \mathrm{~s}, 50^{\circ} \mathrm{C}$ for 60 $\mathrm{s}$, and $72^{\circ} \mathrm{C}$ for $105 \mathrm{~s}$ repeated for 35 cycles; with a final extension of $72^{\circ} \mathrm{C}$ for $10 \mathrm{~min}$. The specific protocol is described at https:// www.earthmicrobiome.org/protocols-and-standards/16s/. Sequencing of bacterial amplicons was performed on Illumina Miseq with Miseq Reagent Kit V2 (Illumina, San Diego, CA, U.S.A.) at Argonne National Laboratory (Argonne, IL, U.S.A.), and sequencing libraries consisted of 150-bp paired-end reads. Sequencing data are deposited in the NCBI Short Read Archive as project PRJNA601860 (sample specific data are shown in Supplementary Table S1).

Amplicon bioinformatic analysis. The sequencing data were analyzed by the DADA2 package (version 1.13.1) to determine abundances of amplicon sequence variants (ASVs) (Callahan et al. 2016). Truncated sequence read length was set to $145 \mathrm{bp}$ to remove lowquality tails based on inspection of quality control profiles. The filtering parameters were set to be truncLen $=c(145,145)$, truncQ $=2$, rm.phix $=$ TRUE, and compress = TRUE. The taxonomic identity of each observed ASV was determined using sequence similarity to representatives in the Ribosomal Database Project (RDP) Classifier (version 11.5). ASVs observed in $<10$ samples were removed. Samples with $<9,000$ reads were removed, resulting in a total of 416 samples (Supplementary Table S1). Each sequencing library was adjusted to 9,000 reads for estimation of ASV abundances, unless otherwise indicated.

Statistical analysis. All statistical analysis was performed in R ( $\mathrm{R}$ Core Team 2019). We estimated $\alpha$ diversity in samples, expressed as Shannon diversity and Chao 1 richness, using the function estimate_richness() included in the phyloseq package, version 1.30.0. $\alpha$ Diversity was estimated for each stand age and sampling day to identify differences between $\mathrm{N}$ fertilization rates. Generalized linear mixed-effect models fit by maximum-likelihood were applied to test the effects of plant aboveground biomass, stand age, and $\mathrm{N}$ fertilization rates on soil $\alpha$ diversity (lme4 package, version 1.1-23 and lmerTest, version 3.1-2). Experimental factors were considered as both main fixed effects in interactions and as a nested random effect within blocks. The Wald $\chi^{2}$ test and least-square means for pairwise $t$ test with false discovery rate correction for multiple comparisons were used to test the significance of relationships between soil microbial richness and diversity and $\mathrm{N}$ fertilization and plant biomass. The rank-based coefficient Kendall's $(\tau)$ nonparametric test was used to estimate the amount and direction of correlation between evaluated factors and $\alpha$-diversity measures.

Permutational multivariate analysis of variance (PERMANOVA) distance matrices was performed with the adonis() function from the vegan package, version 2.5-5, based on the Bray-Curtis dissimilarity distances between samples with $P$ values for the test statistic (pseudo-F) based on 999 permutations. Because the experimental plot was identified as a major factor to structure the microbial composition, PERMANOVA was also performed using the "strata" argument for plot sites to better identify the impacts of stand age and $\mathrm{N}$ fertilization rates. This analysis restricts permutations to samples within each block and was used to quantify variations between and within treatments (e.g., $\mathrm{N}$ fertilization rates and stand age). To test differences in the variability of soil bacterial communities between $\mathrm{N}$ fertilization, we used PERMDISP analyses for each experimental period. Multivariate dispersions, based on distances of observations to their centroid, were first calculated using the betadisper() function of vegan. The mean dispersion was next compared between groups via the permutest() function (based on 999 permutations). Principal coordinates analysis was performed to visualize the dissimilarity among samples using the Bray-Curtis dissimilarity matrix.
We identified representative ASVs within each stand age and required that each ASV be detected with at least 10 reads in a single sample. ASVs were next determined as unique to a stand age or shared between stand ages. To represent these results, a Venn diagram was created using the VennDiagram package (version 1.6.20). To identify significantly enriched ASVs between stand ages, differential abundance analysis based on the negative binomial distribution with Wald's test was performed on the experimental factors of block and $\mathrm{N}$ fertilization rate. This analysis was performed by the function DESeq with nonrarefied data from the $\mathrm{R}$ package DESeq2, version 3.8. Pairwise comparisons to unfertilized treatments were performed, including comparisons $\mathrm{N}$ at 224 to $0 \mathrm{~kg}$ $\mathrm{ha}^{-1}$ and 448 to $0 \mathrm{~kg} \mathrm{ha}^{-1}$ under each stand age of Miscanthus $\times$ giganteus.

Code for all described analysis is available at https://github.com/ germs-lab/LAMPS-miscanthus-microbiome.

\section{RESULTS}

In this study, the Miscanthus $\times$ giganteus plots performed typically for Iowa, yielding between 12 and $30 \mathrm{Mg} \mathrm{ha}^{-1}$ depending on treatment and stand age (Supplementary Table S1). Stand age had a large effect on biomass yield $\left(P_{\text {Age }}=0.0068\right)$. The 3- and 4-year-old stands yielded approximately $20 \%$ more biomass than 2-year-old stands. $\mathrm{N}$ fertilization also had a significant effect on biomass yield, with significant correlations with biomass in 3- and 4-year-old stands but not in 2-year-old stands $\left(P_{\text {Nrate }}<0.0001\right)$ (Supplementary Fig. S2). Fertilized plots yielded up to $38 \%$ more biomass than unfertilized plots but this response changed with stand age $\left(P_{\text {Nrate }} \times\right.$ Age $\left.<0.0001\right)$.

In our Miscanthus $\times$ giganteus soil samples, we observed a total of 31 bacterial phyla and 39,810 ASVs. ASVs associated with Proteobacteria, Actinobacteria, Acidobacteria, Verrucomicrobia, and Bacteroidetes were found to be the most abundant, composing $>80 \%$ by relative abundance (Fig. 1A). Proteobacteria were dominant in the microbiome, with Alphaproteobacteria composing the largest proportion, followed by Betaproteobacteria, Deltaproteobacteria, and Gammaproteobacteria (Fig. 1B). In total, 39,810 ASVs were observed in sampled soils (Fig. 2). ASVs uniquely associated within each stand age were identified, with 1,550, 812, and 701 ASVs identified in 2-, 3-, and 4-year-old stands, respectively. Shared between samples from all three stand ages, 27,315 ASVs (68\% of total) were identified, and these shared ASVs represent highly abundant membership, composing $>80 \%$ of the total observed abundance (Fig. 3A). In contrast, unique ASVs identified from each stand age composed only a small percentage $(<1 \%)$ of total observed abundance (Fig. 3B). These unique ASVs were represented by diverse phyla but were dominated by Proteobacteria (Alphaproteobacteria, Deltaproteobacteria, and Gammaproteobacteria), Actinobacteria, and Acidobacteria.

Overall, we observed no statistically significant differences in $\alpha$ diversity between soils originating from the three stand ages of Miscanthus $\times$ giganteus (Supplementary Table S2). Fertilization rates and stand age interactions were observed to effect $\alpha$ diversity. With increased fertilization rates, we observed that $\alpha$ diversity was negatively affected, especially in 2-year-old stands (Fig. 4). This trend was also found in response to days since fertilization, where $\alpha$ diversity decreased in samples directly after fertilization, particularly in younger stands (Supplementary Table S3; Fig. 4). No significant $(P>0.05)$ correlations between $\alpha$ diversity and days relative to fertilization were observed in 4-year-old stands or samples that received no $\mathrm{N}$ fertilizer.

Next, we identified taxa and their associated phyla that were observed to be significantly different between fertilization rates 
within each stand age (Supplementary Fig. S3). In 2- and 4-year-old plants, 194 and 47 ASVs, respectively, were identified as significantly differentially abundant ASVs under varying treatments of $\mathrm{N}$ rates. The most dominant phyla represented by these ASVs in soils from 2-year plants were Proteobacteria (classes Alphaproteobacteria and Gammaproteobacteria) and Acidobacteria. Dominant phyla associated with these ASVs in soils from 4-year plants also included Proteobacteria (classes Alphaproteobacteria and Gammaproteobacteria), followed by Actinobacteria. Overall, the majority of these ASVs were unique to each stand age, with only 11 of these ASVs identified as present in both 2- and 4-year-old stands. From 3-year-old Miscanthus $\times$ giganteus, only three ASVs were observed to change significantly due to the $\mathrm{N}$ fertilization rates.

Generally, we observed differences in the microbial community structure of the youngest stand age (2 years old) compared with the older stand ages. First, the ASVs identified as significantly enriched in fertilized treatments of 2-year-old Miscanthus $\times$ giganteus samples represented a greater relative abundance compared with those identified in older stand age samples (12 versus $3 \%$ average relative abundance) (Supplementary Fig. S3). Second, many of these ASVs were also found to have a seasonal response to fertilization, and these trends were also more pronounced in 2-year-old stands. In particular, Proteobacteria (especially Alphaproteobacteria and Gammaproteobacteria) and Acidobacteria (especially subdivision 1) increased in relative abundance 5 days after the $448 \mathrm{~kg} \mathrm{ha}^{-1}$ fertilization in both 2- and 4-year-old stands (Supplementary Fig. S4).

$\beta$ Diversity was calculated based on Bray-Curtis dissimilarity for sample-to-sample comparison. PERMANOVA analysis demonstrated that the largest observed variation to affect this diversity was the plot of sample origination $\left(R^{2}=0.244, F=4.520, P=0.001\right)$, followed by stand age $\left(R^{2}=0.075, F=21.652, P=0.001\right)$ and fertilization rates $\left(R^{2}=0.012, F=3.532, P=0.001\right)$. The days

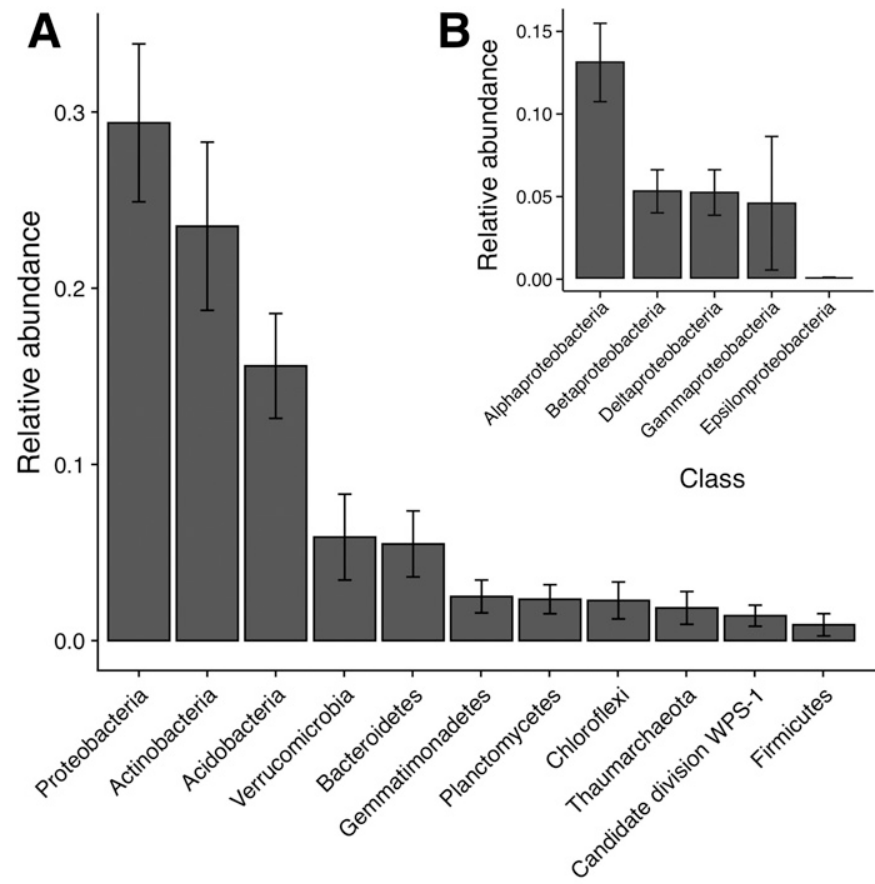

Phylum

Fig. 1. Phylogenetic distribution of Miscanthus $\times$ giganteus microbiome. A, The first 11 most abundant phyla across all samples. B, Classes associated with Proteobacteria. relative to fertilization (i.e., sampling day) also affected the microbial community structure significantly (PERMANOVA, $R^{2}=$ $0.09, F=1.424, P=0.04)$. To further analyze the effects of stand ages and $\mathrm{N}$ fertilization rates, we evaluated differences within a block. All PERMANOVA analyses were also performed without strata as plot, with similar results observed. Comparison of $\beta$ diversity estimates observed between stand ages showed that microbial communities between 2- and 3-year-old Miscanthus $\times$ giganteus (PERMANOVA, $F=22.7, P=0.001$, strata with plot) and 2 - and 4-year-old Miscanthus $\times$ giganteus (PERMANOVA, $F=$ 5.37, $P=0.028$, strata with plot) were significantly different (Supplementary Fig. S5). No significant difference was observed in communities from soils collected from the 3- and 4-year-old stands. Although the most abundant phyla observed in soils from all three plant ages was consistent, the contribution of specific phylum to the total abundance varied, with Verrucomicrobia, Gemmatimonadetes, Planctomycetes, and Thaumarcheota observed as significantly different between all three stand ages (Supplementary Fig. S6).

We evaluated the impact of $\mathrm{N}$ fertilization rates on the heterogeneity of microbial composition within each stand age of Miscanthus $\times$ giganteus. Generally, we observed the largest variation between samples in 2-year-old stand age (PERMDISP, $F=$ 11.81; $P=0.001)$, where significant differences were observed under all $\mathrm{N}$ fertilization rates (Supplementary Fig. S7). In 3-year-old stands, this variation was found to be decreased (PERMDISP, $F=$ 1.49; $P=0.238$ ). In 4-year-old stands, significant dissimilarity between soil communities was detected (PERMDISP, $F=9.15 ; P=$ 0.001 ); however, only significant differences were observed between unfertilized and fertilized groups (PERMDISP, $0 \times 224 \mathrm{~kg}$ ha $^{-1}: P=0.003 ; 0 \times 448 \mathrm{~kg} \mathrm{ha}^{-1}: P=0.001 ; 224 \times 448 \mathrm{~kg} \mathrm{ha}^{-1}: P=$ 0.244).

Finally, we evaluated our ability to predict the soil microbiome diversity from aboveground biomass. Overall, patterns showed increasing biomass with increased fertilization (Supplementary Fig. S2). We developed a predictive model for the effects of the interactions between aboveground biomass and $\mathrm{N}$ fertilization rate on $\alpha$ diversity (Fig. 5). This model showed a positive correlation of biomass and $\alpha$ diversity from fertilized samples which was not present in nonfertilized samples. Although we observed that there is

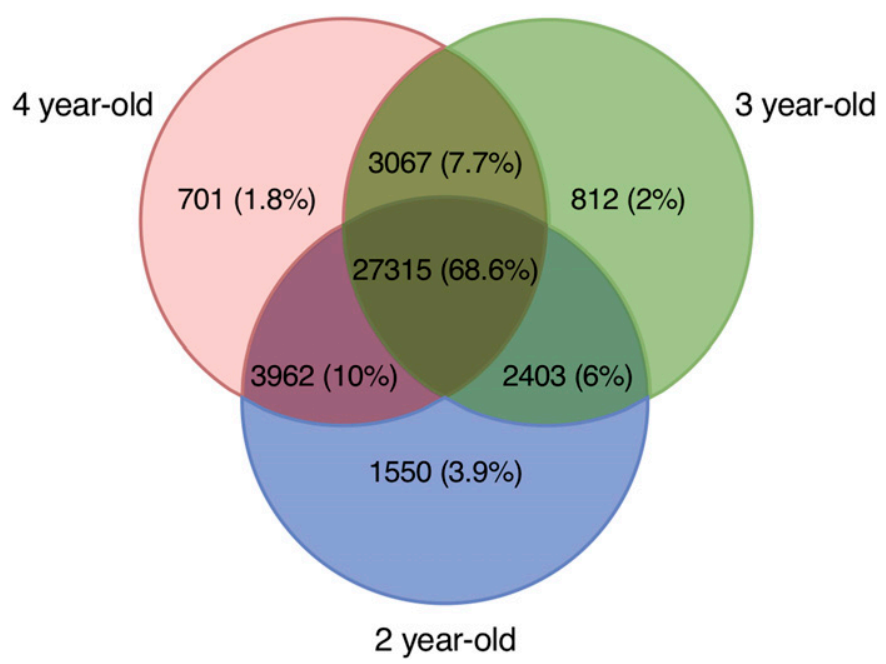

Fig. 2. Venn diagram of the total number (and percentile) of amplicon sequence variations associated with different stand ages of Miscanthus $\times$ giganteus. 
not a direct effect of stand age on $\alpha$ diversity (Supplementary Table S2), we identified a relationship between biomass and $\alpha$ diversity that varies depending on stand age and fertilization rates (Supplementary Fig. S8).

\section{DISCUSSION}

In this study, we explored the relationships between the soil microbial communities of Miscanthus $\times$ giganteus, its stand age, and $\mathrm{N}$ fertilization rates. This community is dominated by Proteobacteria (mainly Alphaproteobacteria), Acidobacteria, and Actinobacteria, which is consistent with previous studies of soil microbiomes (Yan et al. 2017; Zhalnina et al. 2018). The large majority of membership of this community is present across plants from all stand ages within our study (Fig. 3B), though unique taxa were identified as specific to soils from 2-, 3-, and 4-year-old plants.

To determine the impacts of plant stand age and fertilization rates on the overall Miscanthus $\times$ giganteus microbiome, we evaluated several characteristics of the soil microbiomes, including estimations of $\alpha$ diversity and significantly enriched members between treatments. Although there is evidence of a high proportion of the microbial community shared between the samples, impacts of plant stand age and fertilization to alter these communities are illustrated consistently in our results. Between microbiomes originating from plants of varying stand ages, differences between microbial communities were observed to be mainly due to shifts in the proportions of present bacteria rather than different community membership. In response to varying fertilization rates, microbial taxa in each stand age were significantly enriched, with more pronounced shifts in response to fertilization in communities associated with younger stand ages.
Additionally, we observed that the microbial communities associated with younger, 2-year-old stands were more variable in their biodiversity. In comparison, the microbiomes of the 4-year-old stands were observed to have decreased overall $\alpha$ diversity and appeared more similar in composition to 3-year-old than 2-yearold stands. Overall, these results suggest that stand age shifts the underlying soil microbial communities and is consistent with a previous study in Pinus elliottii that showed a significant impact of plant age on microbial communities (Wu et al. 2015).

In the youngest stand age, notable enrichments of Proteobacteria (especially Alphaproteobacteria and Gammaproteobacteria) and Acidobacteria were observed in response to fertilization. Acidobacteria and Proteobacteria have previously been associated with $\mathrm{N}$ cycling and have been observed to be enriched in response to long-term elevated $\mathrm{N}$ in diverse agricultural soils (Dai et al. 2018; Pan et al. 2014). Acidobacteria have previously been found to be sensitive to inorganic and organic nutrient inputs and have been previously associated with nitrate reduction based on both the conservation of nitrate reduction genes and characterization of this activity in isolates (Kielak et al. 2016; Ward et al. 2009). Our results are also consistent with other studies that have observed the enrichment of Alphaproteobacteria and Gammaproteobacteria in Miscanthus $\times$ giganteus in rhizomes after fertilization (Liu and Ludewig 2019). Both Alphaproteobacteria and Gammaproteobacteria have also been observed as having significant membership in the phyllosphere of Miscanthus $\times$ giganteus, with both classes having compensatory patterns over a 10-week growing season (Grady et al. 2019). The consistent observations of the enrichment of these bacteria in Miscanthus $\times$ giganteus suggests that these bacteria may play a role in the microbial response to fertilization. A future research direction is to use functional studies to understand whether these

\section{A Taxa shared by stand age}

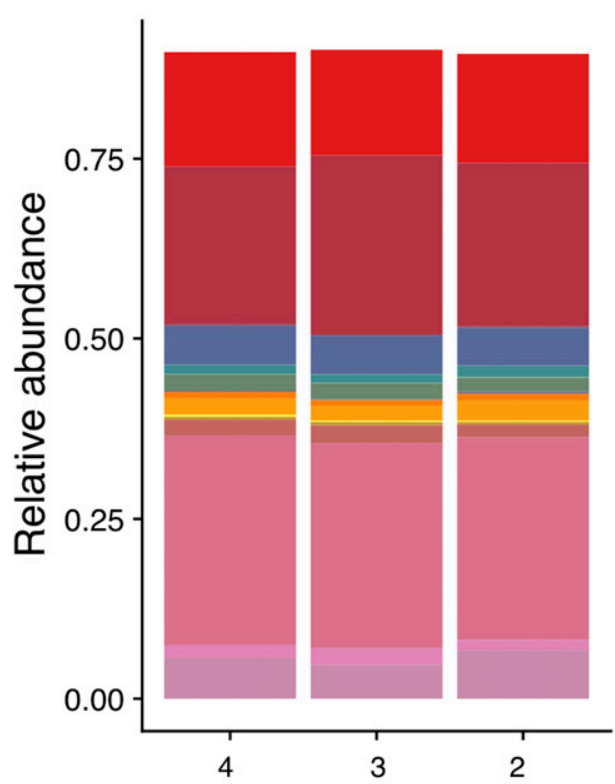

\section{B Taxa unique to each stand age}

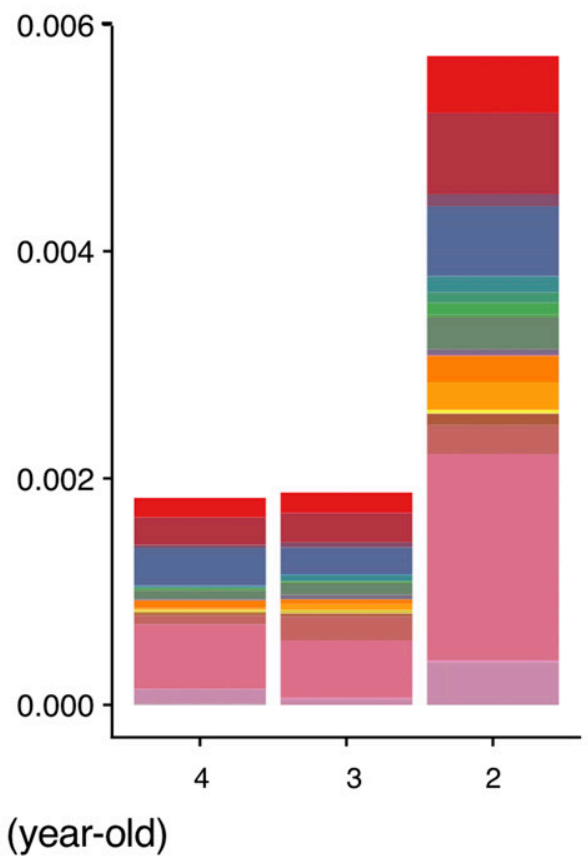

Phylum

Acidobacteria
Actinobacteria
Armatimonadetes
Bacteroidetes
BRC1
candidate_division_WPS-1
candidate_division_WPS-2
Candidatus_Saccharibacteria
Chlamydiae
Chloroflexi
Cyanobacteria/Chloroplast
Deinococcus-Thermus
Diapherotrites
Elusimicrobia
Euryarchaeota
Firmicutes
Gemmatimonadetes
Hydrogenedentes
Ignavibacteriae
Latescibacteria
Microgenomates
Nitrospirae
Pacearchaeota
Parcubacteria
Planctomycetes
Proteobacteria
Spirochaetes
Thaumarchaeota
Verrucomicrobia
Woesearchaeota
SR1

Fig. 3. A, Taxonomic distribution of the amplicon sequence variations (ASVs) shared by soils from each stand age of Miscanthus $\times$ giganteus as measured during the summer growing season in 2018. B, Taxonomic distribution of the ASVs unique to each stand age of Miscanthus $\times$ giganteus. 
differences in microbial communities are attributed to functional changes or benefits to the plant or soils.

In association with our observations that specific microbial membership in older Miscanthus stands have a less pronounced response to fertilization, we also observed that the $\alpha$ diversity of older stand ages were generally less variable in response to fertilization compared with $\alpha$ diversity estimated in younger stand ages. Our results consistently suggest that interactions between
4 year-old

A

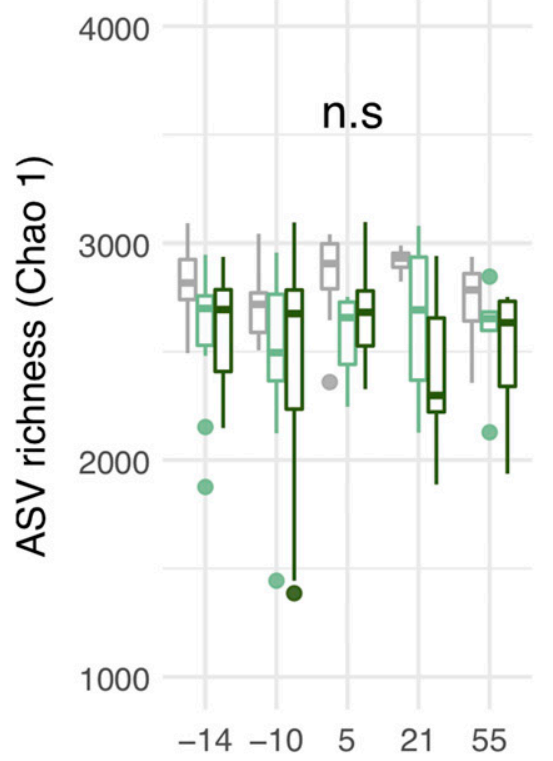

D

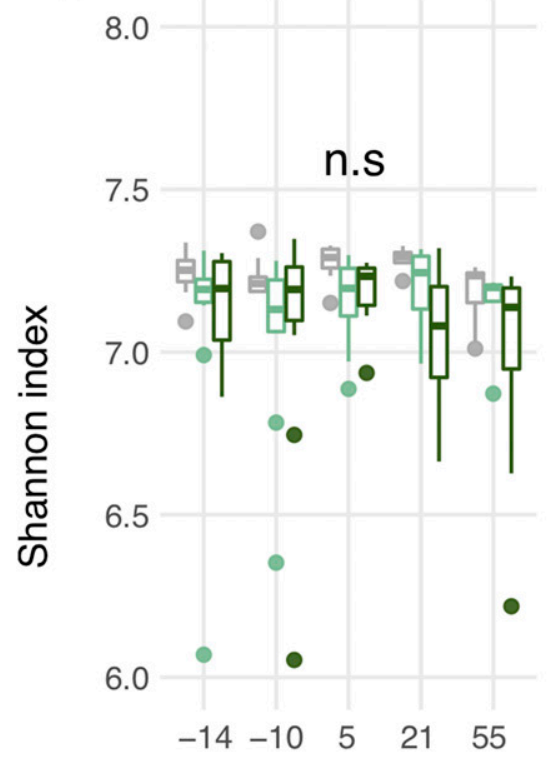

B

3 year-old

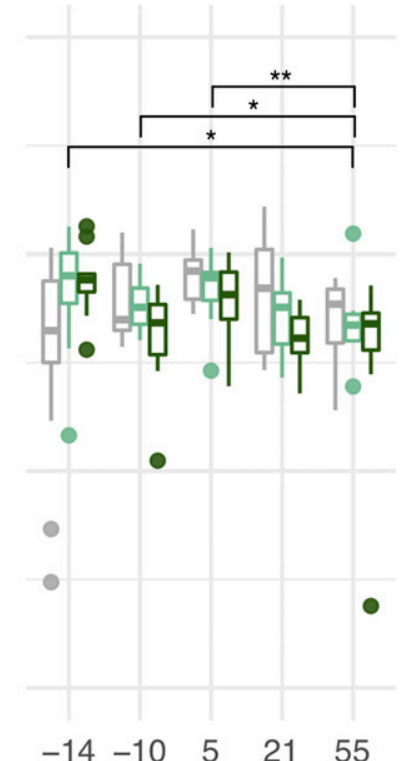

Sampling day

E

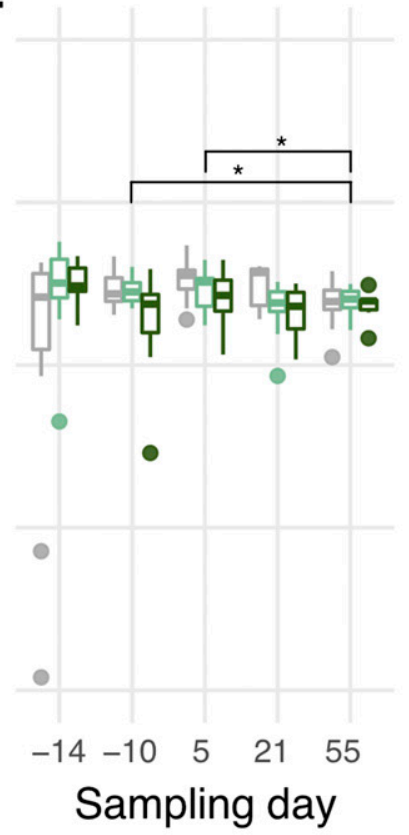

2 year-old

C

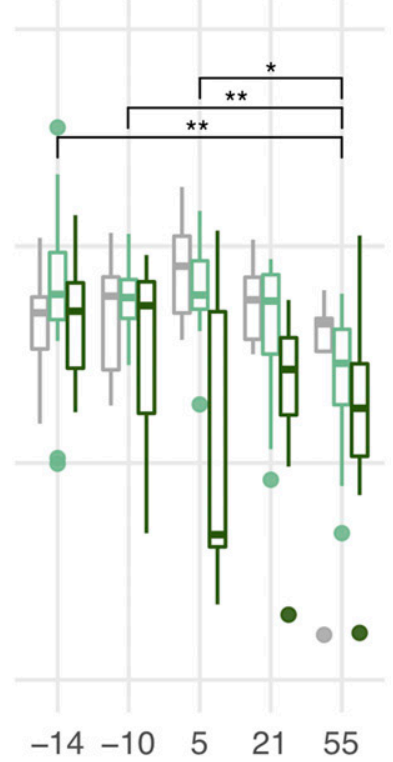

$\mathbf{F}$

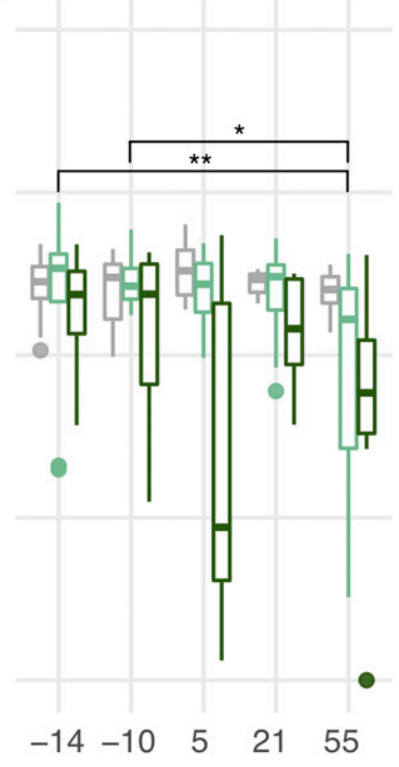

\section{Nitrogen fertilization $\left(\mathrm{kg} \mathrm{ha}^{-1}\right)$ \\ 追 0 追 224 追 448}

Fig. 4. Short-term effect of nitrogen fertilization on the $\alpha$ diversity of soil bacterial communities in Miscanthus $\times$ giganteus planting areas by stand ages. Amplicon sequence variation (ASV) Chao 1 estimated richness for A, 4-year-old; B, 3-year-old; and C, 2-year-old stand ages and Shannon diversity estimates for D, 4-year-old; E, 3-year-old; and F, 2-year-old stand ages shown for varying fertilization rates and over the season. Sampling days are reported relative to the day of fertilizer application. Asterisks indicate significant differences between sampling days; * and ${ }^{* *}$ indicate $P<0.05$ and 0.01 , respectively, and n.s. = not significant. 
stand age and fertilization are important to the diversity observed in Miscanthus $\times$ giganteus. $\mathrm{N}$ fertilization has been previously shown to cause shifts of microbial communities in other plant studies (Dai et al. 2018; Fierer et al. 2012; Yu et al. 2016) but, within Miscanthus $\times$ giganteus, previous studies have shown little effect of $\mathrm{N}$ fertilization on soil communities (Li et al. 2016; Liu and Ludewig 2019). Our results indicate that stand age can influence the Miscanthus $\times$ giganteus microbial community response to fertilization and, thus, $\mathrm{N}$ availability to the plants. Over multiple growing seasons, plants within aged stands can accumulate increased dead plant organs (litter and roots) both above and below the soil surface and also will develop more mature rhizomes. Potentially, the decreased heterogeneity and variability in the response of the microbiome of older Miscanthus $\times$ giganteus is related to its perennial growth and more consistency in the availability of nutrients.

Our observations of the role of stand ages in response to fertilization are also consistent with the yield variability at this site (Tejera et al. 2019). We compared observations of $\alpha$ diversity within soil microbiomes with aboveground biomass production observed during this sampling year. We identified significant relationships between $\alpha$ diversity, stand ages, fertilization, and aboveground biomass production, with general patterns of increased aboveground biomass with increased $\alpha$ diversity under fertilized conditions. Overall, this result highlights a relationship between microbiome, plant productivity, and fertilization practices. Because stands of different ages were planted in different years, possible confounding factors to these observations are the conditions during the establishment of stands (e.g., climate conditions during the year of planting). Soil properties such as $\mathrm{pH}$, climate, and organic carbon availability have previously been shown to affect associated microbiomes (Fierer 2017; Lauber et al. 2009). The year of planting has been previously reported to significantly affect biomass yield along with stand age, with planting condition associated with larger effects on 1-year-old stands but minimal compared with age effects after the second year of growth (Tejera et al. 2019). Conditions associated with planting, especially rhizome condition and weather conditions, have been shown to influence stand performance in subsequent years at climatically similar locations in North America and Europe (Lewandowski et al. 2016; Maughan et al. 2012).

Overall, this study supports the use of microbial characterization to understand Miscanthus $\times$ giganteus productivity and highlights the need to consider plant age in developing management strategies. Our observations that there are consistent bacterial communities associated with Miscanthus $\times$ giganteus that shift in response to plant and soil traits justifies future research to better link this microbiome with plant productivity and sustainability. This study specifically focuses on the bacterial community within the Miscanthus $\times$ giganteus soil microbiome. Understanding the role and interactions of other living organisms in the soil (e.g., fungi, nematodes, and so on) and their interactions with nutrients represents another opportunity for future research. Additionally, there is a need to obtain better functional information to understand the response of the Miscanthus $\times$ giganteus bacterial communities to fertilization and how this helps to meet the $\mathrm{N}$ needs of Miscanthus $\times$ giganteus over varying plant ages.

\section{ACKNOWLEDGMENTS}

The DNA sequencing in this study was performed at Environmental Sample Preparation and Sequencing Facility at Argonne National Laboratory. Any opinions, findings, and conclusions or recommendations expressed in this publication are those of the author(s) and do not necessarily reflect the views of the U.S.
A

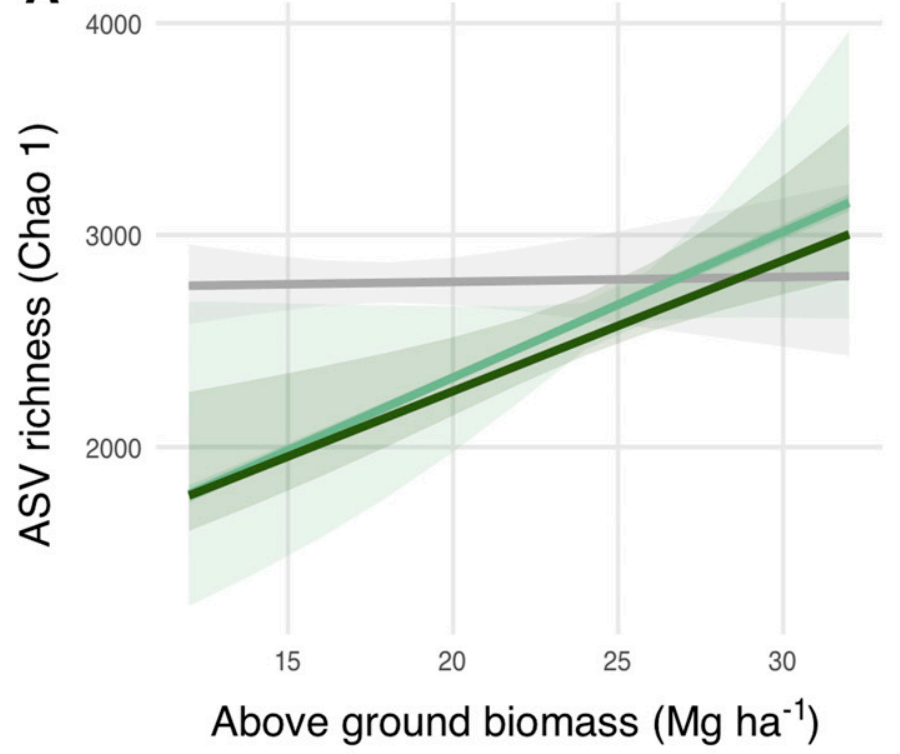

B

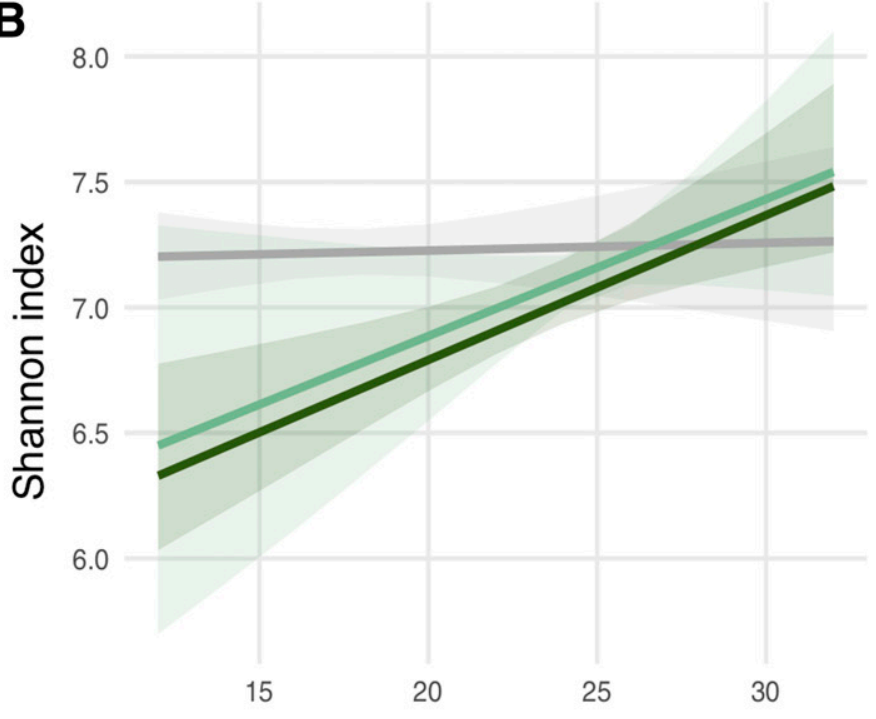

Above ground biomass $\left(\mathrm{Mg} \mathrm{ha}^{-1}\right)$

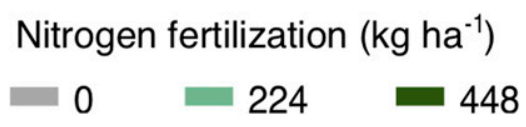

Fig. 5. $\alpha$-Diversity estimates of A, richness by estimated amplicon sequence variation (ASV) Chao 1 and $\mathbf{B}$, Shannon diversity of bacterial communities predicted by the interaction between nitrogen fertilization and Miscanthus $\times$ giganteus aboveground biomass. Estimates are from predicted marginal effects. 
Department of Energy, USDA, Leopold Center for Sustainable Agriculture, or Iowa State University.

\section{LITERATURE CITED}

Arundale, R. A., Dohleman, F. G., Heaton, E. A., McGrath, J. M., Voigt, T. B., and Long, S. P. 2014. Yields of Miscanthus $\times$ giganteus and Panicum virgatum decline with stand age in the Midwestern USA. GCB Bioenergy 6:1-13.

Beale, C. V., and Long, S. P. 1997. Seasonal dynamics of nutrient accumulation and partitioning in the perennial C4-grasses Miscanthus $\times$ giganteus and Spartina cynosuroides. Biomass Bioenergy 12:419-428.

Cadoux, S., Riche, A. B., Yates, N. E., and Machet, J. M. 2012. Nutrient requirements of Miscanthus $\times$ giganteus: Conclusions from a review of published studies. Biomass Bioenergy 38:14-22.

Callahan, B. J., McMurdie, P. J., Rosen, M. J., Han, A. W., Johnson, A. J. A., and Holmes, S. P. 2016. DADA2: High-resolution sample inference from Illumina amplicon data. Nat. Methods 13:581-583.

Christian, D. G., Poulton, P. R., Riche, A. B., and Yates, N. E. 1997. The recovery of $15 \mathrm{~N}$-labelled fertilizer applied to Miscanthus $\times$ giganteus. Biomass Bioenergy 12:21-24.

Christian, D. G., Riche, A. B., and Yates, N. E. 2008. Growth, yield and mineral content of Miscanthus $\times$ giganteus grown as a biofuel for 14 successive harvests. Ind. Crops Prod. 28:320-327.

Cosentino, S. L., Patanè, C., Sanzone, E., Copani, V., and Foti, S. 2007. Effects of soil water content and nitrogen supply on the productivity of Miscanthus $\times$ giganteus Greef et Deu. in a Mediterranean environment. Ind. Crops Prod. 25: 75-88.

Dai, Z., Su, W., Chen, H., Barberán, A., Zhao, H., Yu, M., Yu, L., Brookes, P. C., Schadt, C. W., Chang, S. X., and Xu, J. 2018. Long-term nitrogen fertilization decreases bacterial diversity and favors the growth of Actinobacteria and Proteobacteria in agro-ecosystems across the globe. Global Change Biol. 24:3452-3461.

Davis, S. C., Boddey, R. M., Alves, B. J. R., Cowie, A. L., George, B. H., Ogle, S. M., Smith, P., van Noordwijk, M., and van Wijk, M. T. 2013. Management swing potential for bioenergy crops. GCB Bioenergy 5:623-638.

Davis, S. C., Parton, W. J., Dohleman, F. G., Smith, C. M., Del Grosso, S., Kent, A. D., and DeLucia, E. H. 2010. Comparative biogeochemical cycles of bioenergy crops reveal nitrogen-fixation and low greenhouse gas emissions in a Miscanthus $\times$ giganteus agro-ecosystem. Ecosystems (N. Y.) 13: 144-156.

Ercoli, L., Mariotti, M., Masoni, A., and Bonari, E. 1999. Effect of irrigation and nitrogen fertilization on biomass yield and efficiency of energy use in crop production of Miscanthus. Field Crops Res. 63:3-11.

Fierer, N. 2017. Embracing the unknown: Disentangling the complexities of the soil microbiome. Nat. Rev. Microbiol. 15:579-590.

Fierer, N., Lauber, C. L., Ramirez, K. S., Zaneveld, J., Bradford, M. A., and Knight, R. 2012. Comparative metagenomic, phylogenetic and physiological analyses of soil microbial communities across nitrogen gradients. ISME J. 6: 1007-1017.

Głowacka, K., Clark, L. V., Adhikari, S., Peng, J., Stewart, J. R., Nishiwaki, A., Yamada, T., Jørgensen, U., Hodkinson, T. R., Gifford, J., Juvik, J. A., and Sacks, E. J. 2015. Genetic variation in Miscanthus $\times$ giganteus and the importance of estimating genetic distance thresholds for differentiating clones. GCB Bioenergy 7:386-404.

Grady, K. L., Sorensen, J. W., Stopnisek, N., Guittar, J., and Shade, A. 2019. Assembly and seasonality of core phyllosphere microbiota on perennial biofuel crops. Nat. Commun. 10:4135.

Heaton, E. A., Clifton-Brown, J., Voigt, T. B., Jones, M. B., and Long, S. P. 2004. Miscanthus for renewable energy generation: European union experience and projections for Illinois. Mitigation Adapt. Strategies Global Change 9:433-451. https://link.springer.com/content/pdf/10.1023\%2FB\% 3AMITI.0000038848.94134.be.pdf

Heaton, E. A., Dohleman, F. G., and Long, S. P. 2008. Meeting US biofuel goals with less land: The potential of Miscanthus. Global Change Biol. 14: 2000-2014.

Heaton, E. A., Dohleman, F. G., Miguez, A. F., Juvik, J. A., Lozovaya, V., Widholm, J., Zabotina, O. A., McIsaac, G. F., David, M. B., Voigt, T. B. Boersma, N. N., and Long, S. P. 2010. Miscanthus: A promising biomass crop. Adv. Bot. Res. 56:75-137.

Iqbal, Y., Gauder, M., Claupein, W., Graeff-Hönninger, S., and Lewandowski, I. 2015. Yield and quality development comparison between miscanthus and switchgrass over a period of 10 years. Energy 89:268-276.
Keymer, D. P., and Kent, A. D. 2014. Contribution of nitrogen fixation to first year Miscanthus $\times$ giganteus. GCB Bioenergy 6:577-586.

Kielak, A. M., Barreto, C. C., Kowalchuk, G. A., van Veen, J. A., and Kuramae, E. E. 2016. The ecology of acidobacteria: Moving beyond genes and genomes. Front. Microbiol. 7:744.

Lauber, C. L., Hamady, M., Knight, R., and Fierer, N. 2009. Pyrosequencingbased assessment of soil $\mathrm{pH}$ as a predictor of soil bacterial community structure at the continental scale. Appl. Environ. Microbiol. 75:5111-5120.

LeBauer, D., Kooper, R., Mulrooney, P., Rohde, S., Wang, D., Long, S. P., and Dietze, M. C. 2017. BETYdb: A yield, trait, and ecosystem service database applied to second-generation bioenergy feedstock production. GCB Bioenergy 10:61-71.

Lewandowski, I., Clifton-Brown, J., Trindade, L. M., van der Linden, G. C., Schwarz, K.-U., Müller-Sämann, K., Anisimov, A., Chen, C.-L., Dolstra, O., Donnison, I. S., Farrar, K., Fonteyne, S., Harding, G., Hastings, A., Huxley, L. M., Iqbal, Y., Khokhlov, N., Kiesel, A., Lootens, P., Meyer, H., Mos, M., Muylle, H., Nunn, C., Özgüven, M., Roldán-Ruiz, I., Schüle, H., Tarakanov, I., van der Weijde, T., Wagner, M., Xi, Q., and Kalinina, O. 2016. Progress on optimizing miscanthus biomass production for the European bioeconomy: Results of the EU FP7 project OPTIMISC. Front. Plant Sci. 7:1620.

Li, D., Voigt, T. B., and Kent, A. D. 2016. Plant and soil effects on bacterial communities associated with Miscanthus $\times$ giganteus rhizosphere and rhizomes. GCB Bioenergy 8:183-193.

Liu, Y., and Ludewig, U. 2019. Nitrogen-dependent bacterial community shifts in root, rhizome and rhizosphere of nutrient-efficient Miscanthus $\times$ giganteus from long-term field trials. GCB Bioenergy 11:1334-1347.

Loughin, T. M. 2006. Improved experimental design and analysis for long-term experiments. Crop Sci. 46:2492-2502.

Maughan, M., Bollero, G., Lee, D. K., Darmody, R., Bonos, S., Cortese, L., Murphy, J., Gaussoin, R., Sousek, M., Williams, D., Williams, L., Miguez, F., and Voigt, T. 2012. Miscanthus $\times$ giganteus productivity: The effects of management in different environments. GCB Bioenergy 4:253-265.

Miguez, F. E., Maughan, M., Bollero, G. A., and Long, S. P. 2012. Modeling spatial and dynamic variation in growth, yield, and yield stability of the bioenergy crops Miscanthus $\times$ giganteus and Panicum virgatum across the conterminous United States. GCB Bioenergy 4:509-520.

Miguez, F. E., Villamil, M. B., Long, S. P., and Bollero, G. A. 2008. Metaanalysis of the effects of management factors on Miscanthus $\times$ giganteus growth and biomass production. Agric. For. Meteorol. 148:1280-1292.

Moreau, D., Bardgett, R. D., Finlay, R. D., Jones, D. L., and Philippot, L. 2019. A plant perspective on nitrogen cycling in the rhizosphere. Funct. Ecol. 33: 540-552.

Oates, L. G., Duncan, D. S., Sanford, G. R., Liang, C., and Jackson, R. D. 2016. Bioenergy cropping systems that incorporate native grasses stimulate growth of plant-associated soil microbes in the absence of nitrogen fertilization. Agric. Ecosyst. Environ. 233:396-403.

Pan, Y., Cassman, N., De Hollander, M., Mendes, L. W., Korevaar, H., Geerts, R. H. E. M., Van Veen, J. A., and Kuramae, E. E. 2014. Impact of long-term N, P, $\mathrm{K}$, and NPK fertilization on the composition and potential functions of the bacterial community in grassland soil. FEMS Microbiol. Ecol. 90:195-205.

R Core Team. 2019. R: A Language and Environment for Statistical Computing. R Foundation for Statistical Computing, Vienna, Austria. https://www.rproject.org/

Rinta-Kanto, J. M., Ouellette, A. J. A., Boyer, G. L., Twiss, M. R., Bridgeman, T. B., and Wilhelm, S. W. 2005. Quantification of toxic Microcystis spp. during the 2003 and 2004 blooms in western Lake Erie using quantitative realtime PCR. Environ. Sci. Technol. 39:4198-4205.

Robertson, G. P., Hamilton, S. K., Barham, B. L., Dale, B. E., Izaurralde, R. C., Jackson, R. D., Landis, D. A., Swinton, S. M., Thelen, K. D., and Tiedje, J. M. 2017. Cellulosic biofuel contributions to a sustainable energy future: Choices and outcomes. Science 356:eaal2324.

Stępień, W., Górska, E. B., Pietkiewicz, S., and Kalaji, M. H. 2014. Long-term mineral fertilization impact on chemical and microbiological properties of soil and Miscanthus $\times$ giganteus yield. Plant Soil Environ. 60:117-122.

Tao, K., Kelly, S., and Radutoiu, S. 2019. Microbial associations enabling nitrogen acquisition in plants. Curr. Opin. Microbiol. 49:83-89.

Teat, A. L., Neufeld, H. S., Gehl, R. J., and Gonzales, E. 2015. Growth and yield of Miscanthus $\times$ giganteus grown in fertilized and biochar-amended soils in the Western North Carolina Mountains. Castanea 80:45-58.

Tejera, M., Boersma, N., Vanloocke, A., Archontoulis, S., Dixon, P., Miguez, F., and Heaton, E. 2019. Multi-year and multi-site establishment of the perennial biomass crop Miscanthus $\times$ giganteus using a staggered start design to elucidate N response. BioEnergy Res. 12:471-483. 
Wang, D., Portis, A. R., Moose, S. P., and Long, S. P. 2008. Cool C 4 photosynthesis: Pyruvate $\mathrm{P}_{\mathrm{i}}$ dikinase expression and activity corresponds to the exceptional cold tolerance of carbon assimilation in Miscanthus $\times$ giganteus. Plant Physiol. 148:557-567.

Ward, N. L., Challacombe, J. F., Janssen, P. H., Henrissat, B., Coutinho, P. M., Wu, M., Xie, G., Haft, D. H., Sait, M., Badger, J., Barabote, R. D., Bradley, B., Brettin, T. S., Brinkac, L. M., Bruce, D., Creasy, T., Daugherty, S. C., Davidsen, T. M., DeBoy, R. T., Detter, C., Dodson, R. J., Durkin, A. S., Ganapathy, A., Gwinn-Giglio, M., Han, C. S., Khouri, H., Kiss, H., Kothari, S. P., Madupu, R., Nelson, K. E., Nelson, W. C., Paulsen, I., Penn, K., Ren, Q., Rosovitz, M. J., Selengut, J. D., Shrivastava, S., Sullivan, S. A., Tapia, R., Thompson, L. S., Watkins, K. L., Yang, Q., Yu, C., Zafar, N., Zhou, L., and Kuske, C. R. 2009. Three genomes from the phylum Acidobacteria provide insight into the lifestyles of these microorganisms in soils. Appl. Environ. Microbiol. 75:2046-2056.
Wu, Z., Elizabeth Haack, S., Lin, W., Li, B., Wu, L., Fang, C., and Zhang, Z. 2015. Soil microbial community structure and metabolic activity of Pinus elliottii plantations across different stand ages in a subtropical area. PLoS One 10:e0135354.

Yan, G., Xing, Y., Xu, L., Wang, J., Dong, X., Shan, W., Guo, L., and Wang, Q. 2017. Effects of different nitrogen additions on soil microbial communities in different seasons in a boreal forest. Ecosphere 8:e01879.

Yu, C., Hu, X., Deng, W., Li, Y., Han, G., and Xiong, C. 2016. Response of bacteria community to long-term inorganic nitrogen application in mulberry field soil. PLoS One 11:e0168152.

Zhalnina, K., Louie, K. B., Hao, Z., Mansoori, N., da Rocha, U. N., Shi, S., Cho, H., Karaoz, U., Loqué, D., Bowen, B. P., Firestone, M. K., Northen, T. R., and Brodie, E. L. 2018. Dynamic root exudate chemistry and microbial substrate preferences drive patterns in rhizosphere microbial community assembly. Nat. Microbiol. 3:470-480. 